Check for updates

Cite this: RSC Adv., 2019, 9, 3520

Received 12th December 2018 Accepted 9th January 2019

DOI: $10.1039 / c 8 r a 10195 g$

rsc.li/rsc-advances

\section{Seven new cytotoxic phenylspirodrimane derivatives from the endophytic fungus Stachybotrys chartarum $\uparrow$}

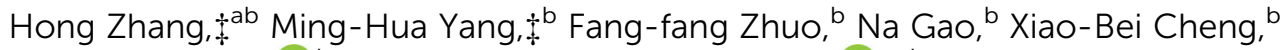 \\ Xiao-Bing Wang, (DD b Yue-Hu Pei ${ }^{* a}$ and Ling-Yi Kong (D) *ab
}

\begin{abstract}
Seven undescribed phenylspirodrimane derivatives, stachybochartins A-G (1-7), and four known analogues (8-11) were isolated from the endophytic fungus Stachybotrys chartarum obtained from Pinellia ternata. Stachybochartins A-D are four rare C-C-coupled dimeric derivatives and stachybochartin $G$ features a seco-bisabosqual skeleton. Their structures and configurations were elucidated via spectroscopic analysis, electronic circular dichroism (ECD) calculations, the ECD exciton chirality method and the modified Mosher's method. Stachybochartins A-D and G displayed cytotoxic activities against MDA-MB231 breast cancer cells and $\mathrm{U}-2 \mathrm{OS}$ osteosarcoma cells, with $\mathrm{IC}_{50}$ values ranging from 4.5 to $21.7 \mu \mathrm{M}$. Stachybochartins $\mathrm{C}$ and $\mathrm{G}$ exerted strong anti-proliferative activities against $\mathrm{U}-2 \mathrm{OS}$ cells in concentration- and time-dependent manners and induced apoptosis.
\end{abstract}

\section{Introduction}

Phenylspirodrimanes are a group of meroterpenoids in which a benzene ring attaches to a drimane sesquiterpene, forming a spirofuran structure. They are particular metabolites that have only been discovered from two fungal genera, Stachybotrys and Memnoniella. ${ }^{1}$ Phenylspirodrimane members have been reported to have diverse biological activities, such as antiosteoporosis activity, ${ }^{2}$ the ability to inhibit immune-complex disease $^{3,4}$ and tyrosine kinase receptors, ${ }^{5}$ and antihyperlipidemic effects. ${ }^{6}$ Due to their unique structures and potential medical applications, chemists are also interested in the synthesis of phenylspirodrimanes and have developed different processes to totally synthesize several bioactive examples, like K-76, L-671, and corallidictyals A-D. ${ }^{7-9}$ It is worth noting that a few derivatives of phenylspirodrimanes have been found as dimers. The two monomers in dimers such as stachybocins $\mathrm{A}-\mathrm{C}^{\mathbf{1 0 , 1 1}}$ are normally linked through different alkyl diamine chains, which are presumably derived from different amino acids. Chartarlactam $\mathrm{L}$ was the first dimer reported with

${ }^{a}$ School of Traditional Chinese Materia Medica, Shenyang Pharmaceutical University, Key Laboratory of Structure-Based Drug Design and Discovery (Shenyang Pharmaceutical University), Ministry of Education, Wenhua Road 103, Shenyang 110016, China. E-mail: peiyueh@vip.163.com; Fax: +86-25-83271405; Tel: +86-2583271405

bJiangsu Key Laboratory of Bioactive Natural Product Research, State Key Laboratory of Natural Medicines, China Pharmaceutical University, 24 Tong Jia Xiang, Nanjing 210009, People's Republic of China.E-mail: cpu_lykong@126.com

$\dagger$ Electronic supplementary information (ESI) available. See DOI: $10.1039 / \mathrm{c} 8 \mathrm{ra10195} \mathrm{g}$

\$ These authors contributed equally. a $\mathrm{C}_{8^{\prime}}-\mathrm{C}_{8^{\prime \prime \prime}}$ linkage ${ }^{6,12}$ and, thereafter, two dimers, stachartone $\mathrm{A}$ and stachartarin $\mathrm{A}^{\mathbf{1 3 , 1 4}}$ were reported to unusually dimerize through the formation of a 2-phenyl-1-indanone fragment. The dimers were also found to possess potential biological activities that were different to those of the monomers, such as antibacterial activities, HIV-1 protease inhibitory effects, and potential ET receptor antagonists. ${ }^{\mathbf{1 0 1 1}, 15}$

Recently, during metabolite research into endophytic fungi from Pinellia ternata, ${ }^{16-19}$ chemical investigation of the strain Stachybotrys chartarum PT2-12 led to the discovery of four phenylspirodrimane $\mathrm{C}-\mathrm{C}$-coupled dimers (1-4) and three new monomers (5-7), along with four known examples (8-11) (Fig. 1). Differently to the $\mathrm{C}_{8^{\prime}}-\mathrm{C}_{8^{\prime \prime \prime}}$ linkage in chartarlactam $\mathrm{L}{ }^{\mathbf{6}}$ the two monomers in $\mathbf{1}$ and $\mathbf{2}$ were dimerized through the unusual $\mathrm{C}_{7^{\prime}}-\mathrm{C}_{7^{\prime \prime \prime}}$ linkage. The isolates were assayed for their cytotoxic activities against three human cancer cell lines (MDAMB-231, U-2OS and MCF-7). Stachybochartins A-D and G showed potent cytotoxicity against MDA-MB-231 and U-2OS cells and stachybochartins $\mathrm{C}$ and $\mathrm{G}$ were found to exert significant anti-proliferative activities against U-2OS cells through the activation of caspase-dependent apoptosis. Herein, the isolation, structural elucidation, and cytotoxic activities of these stachybochartins are described.

\section{Results and discussion}

The molecular formula of stachybochartin A (1) was determined as $\mathrm{C}_{46} \mathrm{H}_{62} \mathrm{O}_{10}$, from the positive HRESIMS ion peak at $m / z: 797.4232[\mathrm{M}+\mathrm{Na}]^{+}$(calcd for $\mathrm{C}_{46} \mathrm{H}_{62} \mathrm{NaO}_{10}$ : 797.4235), revealing 16 degrees of unsaturation. In the ${ }^{1} \mathrm{H}$ NMR spectrum, the obviously recognized signals were one aromatic 


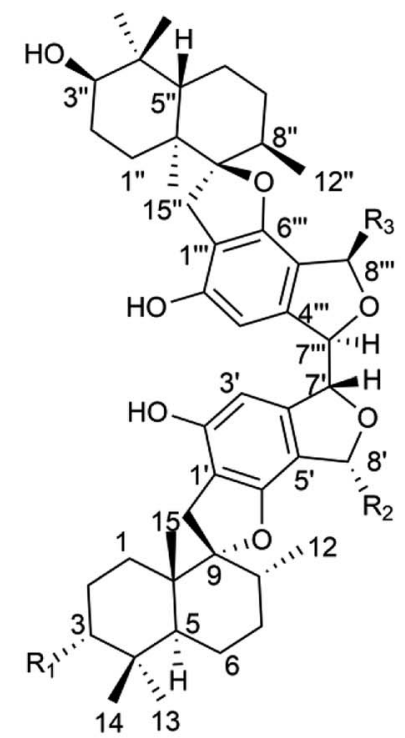

$$
\begin{aligned}
& 1 \mathrm{R}_{1}=\mathrm{OH}, \mathrm{R}_{2}=\mathrm{OH}, \mathrm{R}_{3}=\mathrm{OH} \\
& 2 \mathrm{R}_{1}=\mathrm{OAC}, \mathrm{R}_{2}=O \mathrm{OCH}_{3}, \mathrm{R}_{3}=\mathrm{OCH}_{3}
\end{aligned}
$$

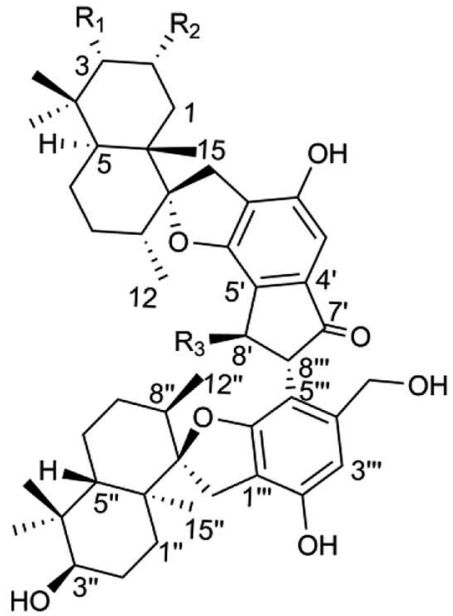

$3 \mathrm{R}_{1}=\mathrm{OH}, \mathrm{R}_{2}=\mathrm{H}, \mathrm{R}_{3}=\mathrm{OCH}_{3}$ $4 \mathrm{R}_{1}=\mathrm{OAc}, \mathrm{R}_{2}=\mathrm{OAc}, \mathrm{R}_{3}=\mathrm{OH}$

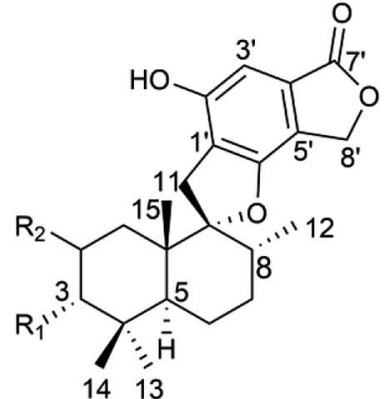

$5 \mathrm{R}_{1}=\mathrm{OAc}, \mathrm{R}_{2}=\alpha-\mathrm{OH}$ $8 \mathrm{R}_{1}=\mathrm{OAc}, \mathrm{R}_{2}=\mathrm{H}$ $9 \mathrm{R}_{1}=\mathrm{OH}, \mathrm{R}_{2}=\mathrm{H}$

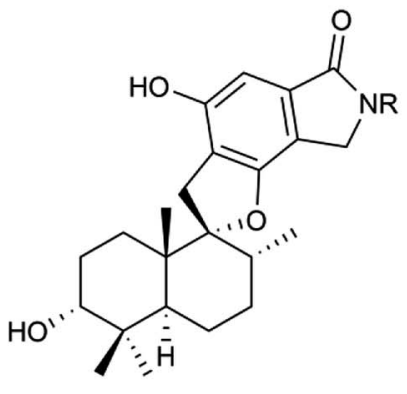

$6 \mathrm{R}=\stackrel{9^{\prime}}{\mathrm{C}} \mathrm{H}_{2} \stackrel{10^{\prime}}{\mathrm{C}} \mathrm{H}_{2} \mathrm{OCOCH}_{3}$ $10 \mathrm{R}=\mathrm{CH}_{2} \mathrm{CH}_{2} \mathrm{OH}$ $11 \mathrm{R}=\mathrm{H}$

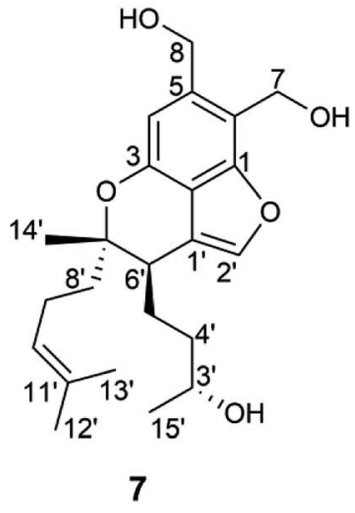

Fig. 1 The structures of compounds 1-11

singlet $\left(\delta_{\mathrm{H}} 6.31, \mathrm{~s}\right)$, three oxymethine signals $\left(\delta_{\mathrm{H}} 5.70, \mathrm{~s} ; \delta_{\mathrm{H}}\right.$ $\left.4.72, \mathrm{~s} ; \delta_{\mathrm{H}} 3.33, \mathrm{~m}\right)$, and four methyl signals $\left(\delta_{\mathrm{H}} 1.03,3 \mathrm{H}, \mathrm{s} ; \delta_{\mathrm{H}}\right.$ $0.97,3 \mathrm{H}, \mathrm{s} ; \delta_{\mathrm{H}} 0.88,3 \mathrm{H}, \mathrm{s} ; \delta_{\mathrm{H}} 0.76,3 \mathrm{H}, \mathrm{d}, J=6.4 \mathrm{~Hz}$ ), while the remaining signals were from twelve protons in the field range from $\delta_{\mathrm{H}} 2.00$ to 3.00. Analysis of ${ }^{13} \mathrm{C}$ NMR and DEPT spectra revealed the presence of 23 carbon signals from four methyl $\left(\delta_{\mathrm{C}} 29.0,23.0,16.6\right.$, and 16.0), five methylene $\left(\delta_{\mathrm{C}} 32.6,32.5\right.$, 26.1, 25.4 and 22.3), six methine $\left(\delta_{\mathrm{C}} 108.7,97.3,76.5,64.1,41.5\right.$ and 38.5), five nonprotonated aromatic $\left(\delta_{\mathrm{C}} 160.7,154.8,134.2\right.$, 114.7 , and 109.6), and three quaternary $\left(\delta_{\mathrm{C}} 98.7,43.2\right.$ and 37.4) carbons. The above data resembled that from stachybotrylactones, yet only showed half the total mass revealed by MS studies. ${ }^{20}$ Therefore, $\mathbf{1}$ was deduced to be a dimeric phenylspirodrimane with a symmetrical structure. HMBC results further confirmed the phenylspirodrimane structure (Fig. 2). The correlations from $\mathrm{H}_{3}-15$ to $\mathrm{H}-1 / \mathrm{H}-5 / \mathrm{H}-9 / \mathrm{H}-10$, from $\mathrm{H}_{3}-14$ to $\mathrm{H}-3 / \mathrm{H}-4$, and from $\mathrm{H}-3$ to $\mathrm{H}-1 / \mathrm{H}-5$ verified the drimane sesquiterpene moiety. Meanwhile, the spirobenzofuran moiety was revealed through correlations from $\mathrm{H}_{2}-11$ to $\mathrm{C}-1^{\prime}$, C-2', C$6^{\prime}, \mathrm{C}-9$, and C-10. It was further noticed that the carbonyl C-7' and the oxygenated methylene $\mathrm{C}-8^{\prime}$ seen in stachybotrylactones ${ }^{20}$ were replaced by the hemiacetal C- $8^{\prime}$ at $\delta_{\mathrm{H}} 5.70 / \delta_{\mathrm{C}}$ 97.3 and the oxygenated methine $\mathrm{C}-7^{\prime}$ at $\delta_{\mathrm{H}} 4.72 / \delta_{\mathrm{C}} 64.1$ in 1. The methine nature of $\mathrm{C}-7^{\prime}$ revealed the $\mathrm{C}-7^{\prime}-\mathrm{C}-7^{\prime \prime \prime}$ bond between the two symmetrical units. This was also evidenced by the HMBC correlations from $\mathrm{H}-7^{\prime}\left(\delta_{\mathrm{H}} 4.72\right)$ to $\mathrm{C}-7^{\prime}, \mathrm{C}-3^{\prime}, \mathrm{C}-4^{\prime}$, and $\mathrm{C}-8^{\prime}$, as well as from $\mathrm{H}-8^{\prime}\left(\delta_{\mathrm{H}} 5.70\right)$ to $\mathrm{C}-4^{\prime}, \mathrm{C}-5^{\prime}, \mathrm{C}-6^{\prime}$, and C$7^{\prime}$. The monomeric core in $\mathbf{1}$ was deduced to possess the same relative configuration as those of stachybotrylactones from ROESY analysis (Fig. 2). The key ROESY correlations of $\mathrm{H}-3 / \mathrm{H}_{3}-$ $14 / \mathrm{H}_{3}-15, \quad \mathrm{H}_{3}-15 / \mathrm{H}-11 \mathrm{a} / \mathrm{H}-8, \mathrm{H}-11 \mathrm{~b} / \mathrm{H}_{3}-12$, and $\mathrm{H}-5 / \mathrm{H}_{3}-13$ confirmed the $\beta$-orientations of $\mathrm{H}-3, \mathrm{H}_{3}-14, \mathrm{H}_{3}-15, \mathrm{H}_{2}-11$ and $\mathrm{H}-8$, while $\mathrm{H}-5, \mathrm{H}_{3}-12$, and $\mathrm{H}_{3}-13$ were $\alpha$-oriented. The ROESY correlations from $\mathrm{H}-8^{\prime}$ to $\mathrm{H}_{3}-12$ and $\mathrm{H}-\mathrm{7}^{\prime}$ further revealed that $\mathrm{H}-\mathrm{7}^{\prime}$ and $\mathrm{H}-\mathrm{8}^{\prime}$ were on the same side of the molecular plane. Based on the ECD exciton chirality method, ${ }^{21,22}$ the $(R)$ - 

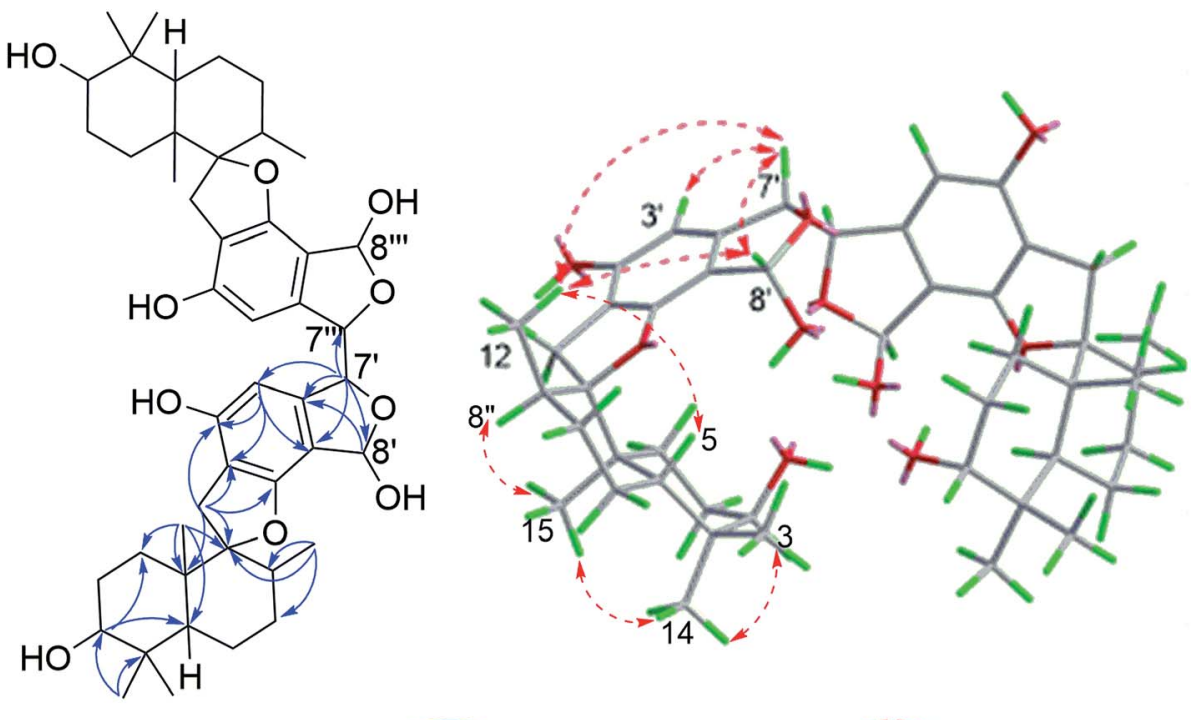

Key HMBC

Key ROESY

Fig. 2 The key HMBC and ROESY correlations for stachybochartin A (1).

configuration of $\mathrm{C}-\mathrm{7}^{\prime} / \mathrm{C}-\mathrm{7}^{\prime \prime \prime}$ was revealed through the negative couplet of the benzene moiety at around $210 \mathrm{~nm}$ (Fig. 3a), which was further confirmed via ECD calculations (Fig. 3b).

Stachybochartin B (2) was determined to have the molecular formula $\mathrm{C}_{50} \mathrm{H}_{68} \mathrm{O}_{11}$, from the HRESIMS ion peak at $m / z$ : $867.4658[\mathrm{M}+\mathrm{Na}]^{+}$. The 1D NMR spectra signals of 2 were apparently double those of $\mathbf{1}$, which indicated that $\mathbf{2}$ was an analogue of $\mathbf{1}$ with different substituents. The methylation of the hydroxyl groups at C-8 ${ }^{\prime}$ and C- $8^{\prime \prime \prime}$ and the acetylation of the hydroxyl group at C-3 in 2 were confirmed via the HMBC correlations from $\delta_{\mathrm{H}} 3.66\left(-\mathrm{OCH}_{3}\right)$ to $\mathrm{C}-8^{\prime}$, from $\delta_{\mathrm{H}} 3.67$ $\left(-\mathrm{OCH}_{3}\right)$ to $\mathrm{C}-8^{\prime \prime \prime}$, from $\mathrm{H}-8^{\prime}$ to $\delta_{\mathrm{C}} 56.2\left(-\mathrm{OCH}_{3}\right)$, from $\mathrm{H}-8^{\prime \prime \prime}$ to $\delta_{\mathrm{C}} 56.4\left(-\mathrm{OCH}_{3}\right)$, and from $\mathrm{H}-3\left(\delta_{\mathrm{H}} 4.58\right) / \delta_{\mathrm{H}} 2.00\left(-\mathrm{OCOCH}_{3}\right)$ to $\delta_{\mathrm{C}} 172.5\left(-\mathrm{OCOCH}_{3}\right)$. The relative configurations of the two monomeric units were determined to be identical to those in 1 via ROESY correlations (Fig. S1 $\dagger$ ). In addition, the well matched ECD curves of $\mathbf{1}$ and 2 (Fig. S2 $\dagger$ ) established that their absolute configurations are the same. The dimeric compounds of 1 and $\mathbf{2}$ were speculated to be derived from the monomer stachybotrylactone (9), where two monomers formed a C-C bond via a free radical coupling reaction at $\mathrm{C}-\mathrm{7}^{\prime}$ and $\mathrm{C}-7^{\prime \prime \prime}$.

Stachybochartin $\mathrm{C}$ (3) was obtained as a yellow amorphous solid. Its molecular formula $\mathrm{C}_{47} \mathrm{H}_{64} \mathrm{O}_{9}$ with 16 degrees of unsaturation was determined via the positive HRESIMS ion peak at $m / z$ : $795.4447[\mathrm{M}+\mathrm{Na}]^{+}$(calcd for $\mathrm{C}_{47} \mathrm{H}_{64} \mathrm{NaO}_{9}$ : 795.4443). The 1D and 2D NMR data indicated that 3 was another dimer but with a different dimeric mode. Careful analysis of the ${ }^{1} \mathrm{H}^{-}{ }^{1} \mathrm{H}$ COSY correlations revealed two spin systems (C-1-C-3 and C-5-C-12), which further assisted the elucidation of the drimane moieties through the HMBC correlations from $\mathrm{H}_{3}-15$ to $\mathrm{H}-1 / \mathrm{H}-5 / \mathrm{H}-9 / \mathrm{H}-10, \mathrm{H}_{3}-14$ to $\mathrm{H}-3 / \mathrm{H}-4$, and $\mathrm{H}-3$ to $\mathrm{H}-1 / \mathrm{H}-5$. The correlations from $\mathrm{H}_{2}-11$ to $\mathrm{C}-1^{\prime}, \mathrm{C}-2^{\prime}$, C-6 ${ }^{\prime}, \mathrm{C}-$ 9 , and $\mathrm{C}-10$ further confirmed that the attached benzene ring

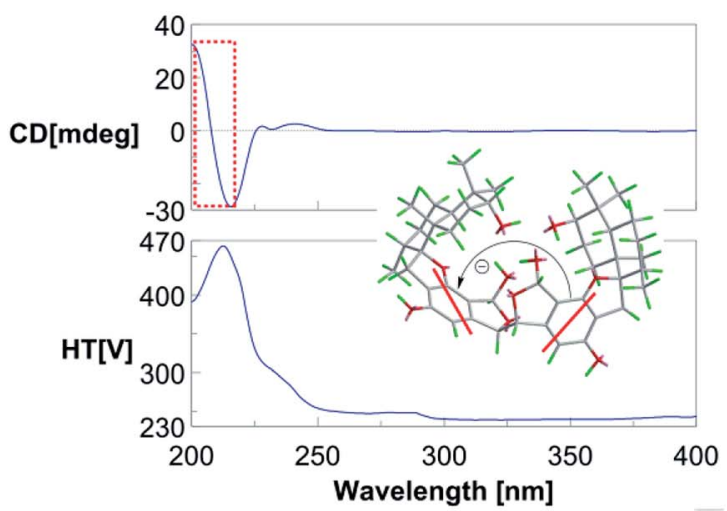

a

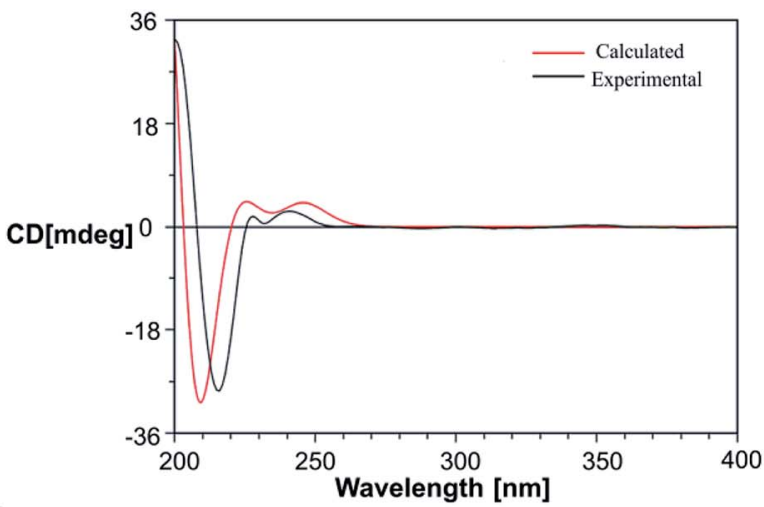

b

Fig. 3 (a) The ECD spectrum of stachybochartin A (1) in MeOH. The negative couplet at around $208 \mathrm{~nm}$ (a negative Cotton effect at $214 \mathrm{~nm}$ and a positive one at $202 \mathrm{~nm}$ ) in the ECD spectrum indicated the $7^{\prime} R, 7^{\prime \prime \prime} R$ configuration in 1; (b) a comparison of the experimental and calculated ECD spectra of 1. 

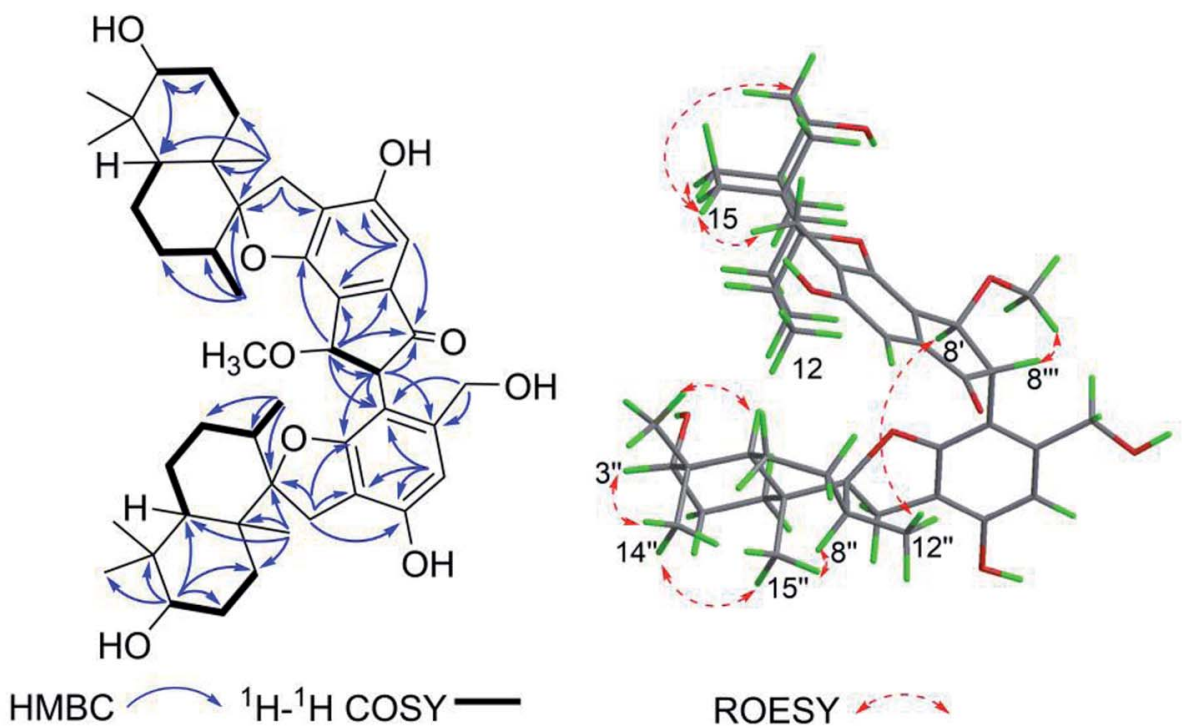

Fig. 4 The key HMBC and ROESY correlations for stachybochartin C (3).

helped form the spirofuran structure. Similar HMBC correlations also established the other monomeric unit. The 2-phenyl1-indanone fragment, as in stachartone $\mathrm{A}^{13,14}$ was mainly determined via $\mathrm{HMBC}$ correlations from $\mathrm{H}-8^{\prime}\left(\delta_{\mathrm{H}} 4.89\right)$ to $\mathrm{C}-4^{\prime}$, $\mathrm{C}-5^{\prime}, \mathrm{C}-6^{\prime}, \mathrm{C}-7^{\prime}$ and $\mathrm{C}-8^{\prime \prime \prime}$ and $\mathrm{H}-8^{\prime \prime \prime}$ to $\mathrm{C}-8^{\prime}, \mathrm{C}-7^{\prime}, \mathrm{C}-4^{\prime \prime \prime}, \mathrm{C}-5^{\prime \prime \prime}$ and C$6^{\prime \prime \prime}$. Meanwhile, an additional methoxyl signal was also observed at ${\mathrm{C}-8^{\prime}}^{\prime}$ in 3 due to $\mathrm{HMBC}$ correlation from $\delta_{\mathrm{H}} 3.72(3 \mathrm{H}, \mathrm{s}$, $\left.-\mathrm{OCH}_{3}\right)$ to C-8 $\left(\delta_{\mathrm{C}} 85.3\right)$. Therefore, the planar structure of 3 was determined as shown. Though ROESY analysis (Fig. 4), the relative configuration of 3 was established to be the same as that of stachartone A. ${ }^{13}$ The ROESY correlations from $\mathrm{H}-3$ to $\mathrm{H}_{3}-14$ / $\mathrm{H}_{3}-15$ and from $\mathrm{H}_{3}-15$ to $\mathrm{H}_{2}-11$ and $\mathrm{H}-8$ revealed that $\mathrm{H}-3, \mathrm{H}_{3}-14$, $\mathrm{H}_{3}-15, \mathrm{H}_{2}-11$ and $\mathrm{H}-8$ had the same orientation, leaving $\mathrm{H}-5, \mathrm{H}_{3}-$ 12 and $\mathrm{H}_{3}-13$ with the opposite orientation. The same NOEs were also observed for the other drimane moiety, which therefore possessed the same relative configuration. Moreover, the correlations between $\mathrm{H}-8^{\prime \prime \prime}$ and $8^{\prime}-\mathrm{OCH}_{3}$ and between $\mathrm{H}-\mathrm{8}^{\prime}$ and $\mathrm{H}_{3}-12^{\prime \prime}$ confirmed that $\mathrm{H}-8^{\prime}$ and $\mathrm{H}-8^{\prime \prime \prime}$ were oriented oppositely and that the two drimane moieties were closely approximated in space. ECD calculations were further used to verify the configuration. As shown in Fig. 5, the 3a calculated spectrum showed overall agreement with the experimental ECD spectrum, which determined the $3 R, 5 S, 8 R, 9 R, 10 S, 8^{\prime} R, 3^{\prime \prime} R, 5^{\prime \prime} S, 8^{\prime \prime} R, 9^{\prime \prime} R, 10^{\prime \prime} S$ and $8^{\prime \prime \prime} R$ configuration of 3 .

The molecular formula $\mathrm{C}_{50} \mathrm{H}_{66} \mathrm{O}_{12}$ of stachybochartin D (4) was determined from HRESIMS data. 1D and 2D NMR data analysis revealed that $\mathbf{4}$ possessed the same dimeric phenylspirodrimane skeleton as 3, but with different substituents. Two additional acetoxyl groups were placed at $\mathrm{C}-2$ and $\mathrm{C}-3$, as established via the HMBC correlations from $\delta_{\mathrm{H}} 1.88(3 \mathrm{H}, \mathrm{s})$ to $\delta_{\mathrm{C}}$ 172.3 and from $\delta_{\mathrm{H}} 2.09(3 \mathrm{H}, \mathrm{s})$ to $\delta_{\mathrm{C}}$ 173.2. Meanwhile, the lack of a methoxyl signal and the chemical shifts of $\mathrm{H}-8^{\prime}\left(\delta_{\mathrm{H}} 5.18\right)$ and C-8 $8^{\prime}\left(\delta_{\mathrm{C}} 75.7\right)$ revealed a hydroxyl group at C- $8^{\prime}$. The relative configuration of $\mathbf{4}$ was deduced to be the same as that of 3 due to their similar ROESY correlations (Fig. S3 $\dagger$ ), and $\mathrm{H}-2$ in 4 had the same orientation as $\mathrm{H}-3$ and $\mathrm{H}_{3}-15$ according to their observed mutual NOEs. The identical ECD curves of $\mathbf{3}$ and $\mathbf{4}$ (Fig. S4†) additionally indicated that their absolute configurations were the same.

The molecular formula of stachybochartin $\mathrm{E}(5), \mathrm{C}_{25} \mathrm{H}_{32} \mathrm{O}_{7}$, was determined from the HRESIMS ion peak at $\mathrm{m} / \mathrm{z}: 467.2038$ $[\mathrm{M}+\mathrm{Na}]^{+}$(calcd for $\mathrm{C}_{25} \mathrm{H}_{32} \mathrm{NaO}_{7}: 467.2040$ ). Its structure was determined to be similar to that of stachybotrylactone acetate $(8)^{23}$ on the basis of their similar NMR data. The difference between them was the appearance of a hydroxyl group at C-2 $\left(\delta_{\mathrm{H}}\right.$ 4.07 , ddd, $J=12.2,4.3,2.6 \mathrm{~Hz} ; \delta_{\mathrm{C}} 65.7$ ) in 5 , which was also evidenced by the HMBC correlations from $\mathrm{H}-2$ to $\mathrm{C}-1$ and $\mathrm{C}-3$. The small coupling constant of $J_{\mathrm{H}-3 / \mathrm{H}-2}(J=2.6 \mathrm{~Hz})$ indicated

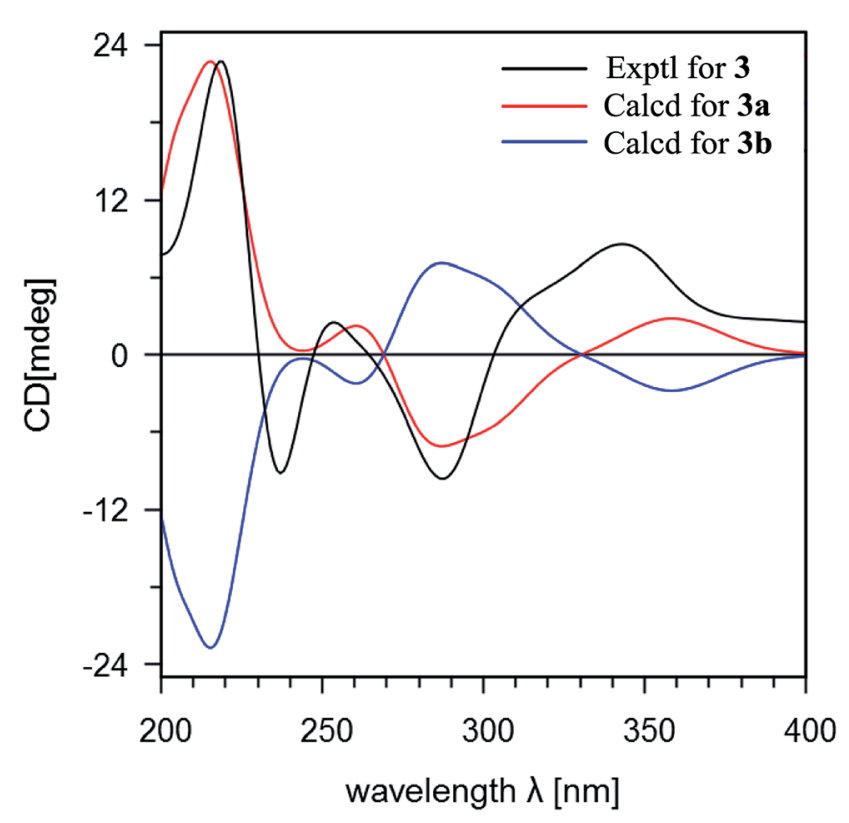

Fig. 5 A comparison of the experimental and calculated ECD spectra of stachybochartin C (3). (3a: 3R, 5S, 8R, 9R, 10S, $8^{\prime} R, 3^{\prime \prime} R, 5^{\prime \prime} S, 8^{\prime \prime} R, 9^{\prime \prime} R$, $10^{\prime \prime} S, 8^{\prime \prime \prime} R$; 3b: 3S, 5R, 8S, 9S, 10R, 8'S, 3"S, 5" R, 8"S, 9"S, 10"R, $8^{\prime \prime \prime} S$ ). 

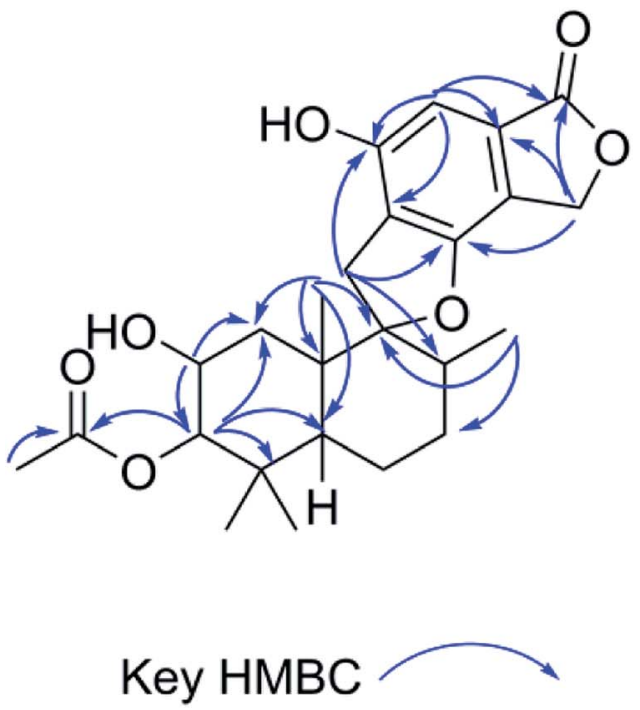
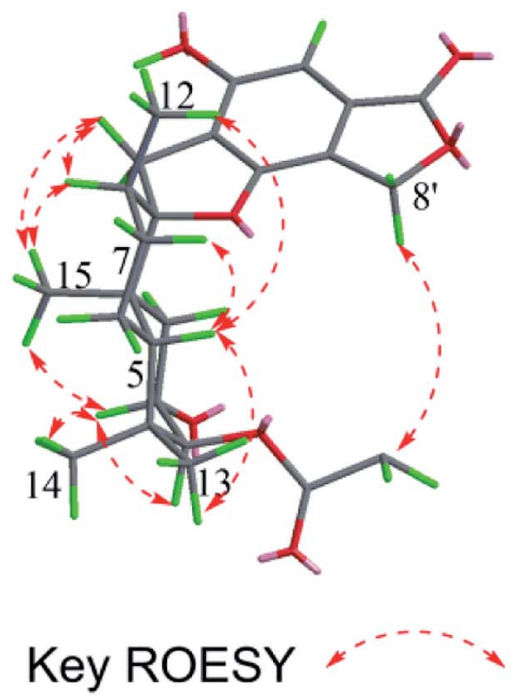

Fig. 6 The key HMBC and ROESY correlations for stachybochartin E (5).

that the orientation of $\mathrm{H}-2$ and $\mathrm{H}-3$ was the same, and the ROESY correlations of $\mathrm{H}-2 / \mathrm{H}_{3}-14 / \mathrm{H}_{3}-15 / \mathrm{H}-3, \mathrm{H}_{3}-15 / \mathrm{H}-8$ and $\mathrm{H}-5 /$ $\mathrm{H}_{3}-13$ further suggested the $\beta$-orientation of $\mathrm{H}_{3}-15, \mathrm{H}-8, \mathrm{H}_{2}-11$, $\mathrm{H}-3$ and $\mathrm{H}-2$ and the $\alpha$-orientation of $\mathrm{H}-5$ and $\mathrm{H}_{3}-12$ (Fig. 6). In the ECD spectrum, the distinctive positive Cotton effect (CE) at $219 \mathrm{~nm}$ and negative CEs at 268 and $339 \mathrm{~nm}$ (Fig. S5 $\dagger$ ) provided evidence for an absolute configuration of $2 R, 3 S, 5 S, 8 R, 9 R$ and $10 S .^{24}$

Stachybochartin $\mathrm{F}$ (6) was assigned the molecular formula of $\mathrm{C}_{27} \mathrm{H}_{38} \mathrm{NO}_{6}$ from positive HRESIMS data. The ${ }^{1} \mathrm{H}$ and ${ }^{13} \mathrm{C} \mathrm{NMR}$ spectra of $\mathbf{6}$ were almost identical to those of stachybotramide (10). ${ }^{23}$ The differences were the additional acetyl group and the upfield-shifted $\mathrm{H}_{2}-10^{\prime}$ of 6 , suggesting that 6 was the $10^{\prime}-\mathrm{OH}$ acetylated derivative of stachybotramide. This deduction was proved through the $\mathrm{HMBC}$ correlation from $\mathrm{H}_{2}-10^{\prime}\left(\delta_{\mathrm{H}} 4.32\right)$ to the carbonyl carbon at $\delta_{\mathrm{C}}$ 172.7. Moreover, the ROESY correlations (Fig. S6 $\dagger$ ) suggested that it had the same relative configuration as that of 5, and their similar CEs (Fig. S7†) confirmed their identical absolute configurations.

Stachybochartin G (7) had the molecular formula $\mathrm{C}_{23} \mathrm{H}_{32} \mathrm{O}_{5}$. Analysis of the NMR data clearly indicated that 7 was closely related to stachybisbin $\mathrm{B},{ }^{25}$ and the absence of an acetyl group indicated the deacetylation of 7-OH in 7. The planar structure of 7 was confirmed via HMBC correlations (Fig. S8 $\dagger$ ). The ROESY correlations of $\mathrm{H}-6^{\prime} / \mathrm{H}_{2}-8^{\prime}$ and $\mathrm{H}_{3}-14^{\prime} / \mathrm{H}_{2}-5^{\prime}$ indicated that $\mathrm{H}_{3}-14^{\prime}$ and $\mathrm{H}-\mathrm{\sigma}^{\prime}$ had opposite orientation, and the identical ECD curve (Fig. S9 $\dagger$ ) to that of stachybisbin B determined the same $6^{\prime} R$ and $7^{\prime} S$ configurations in 7 . In addition, the $3^{\prime} S$ configuration was determined via the modified Mosher's method (Fig. 7). ${ }^{18}$ Therefore, the absolute configuration of 7 was determined to be $3^{\prime} S, 6^{\prime} R$, and $7^{\prime} S$.

All the isolates were evaluated for their cytotoxicity against three human cancer cell lines: MDA-MB-231, MCF-7, and U-2OS. Stachybochartins A-D (1-4) and G (7) displayed activity against the human cancer cell lines MDA-MB-231 and U-2OS, with $\mathrm{IC}_{50}$ values ranging from 4.5 to $21.7 \mu \mathrm{M}$, but all the isolates were inactive $\left(\mathrm{IC}_{50}>50 \mu \mathrm{M}\right)$ against the cell line MCF-7 (Table $\mathrm{S} 1 \dagger$ ).
Stachybochartins C (3) and G (7) showed a more remarkable effect on U-2OS cells than on other cell types, thus their cytotoxic effects were further evaluated on U-2OS cells with doxorubicin (DOX) as a positive control (Fig. 8A). As shown in Fig. 8B, both 3 and 7 significantly inhibited the cell viability in concentration- and time-dependent manners, which was also confirmed by the results of colony formation assays, as shown in Fig. 8C. Together, these data indicated that 3 and 7 inhibited the proliferation of U-2OS cells.

To investigate whether the cytotoxicity was associated with cell apoptosis, we respectively detected the apoptosis of $\mathrm{U}$ 2OS cells after treatment with stachybochartins C (3) and G (7). Compared with the control, the percentage of apoptotic cells increased in a dose-dependent manner for both the stachybochartin $\mathrm{C}$ and $\mathrm{G}$ groups (Fig. 9A), indicating<smiles>CC(C)=CCC[C@]1(C)Oc2cc(CO)c(CO)c3occ(c23)[C@H]1CCC(C)O[Mg]</smiles>

\section{7a:(S)-MTPA ester of 7 7b:(R)-MTPA ester of 7}

Fig. $7 \Delta \delta$ values (in ppm) $=\delta_{S}-\delta_{R}$, obtained for the (S)- and (R)-MPTA esters. 
A
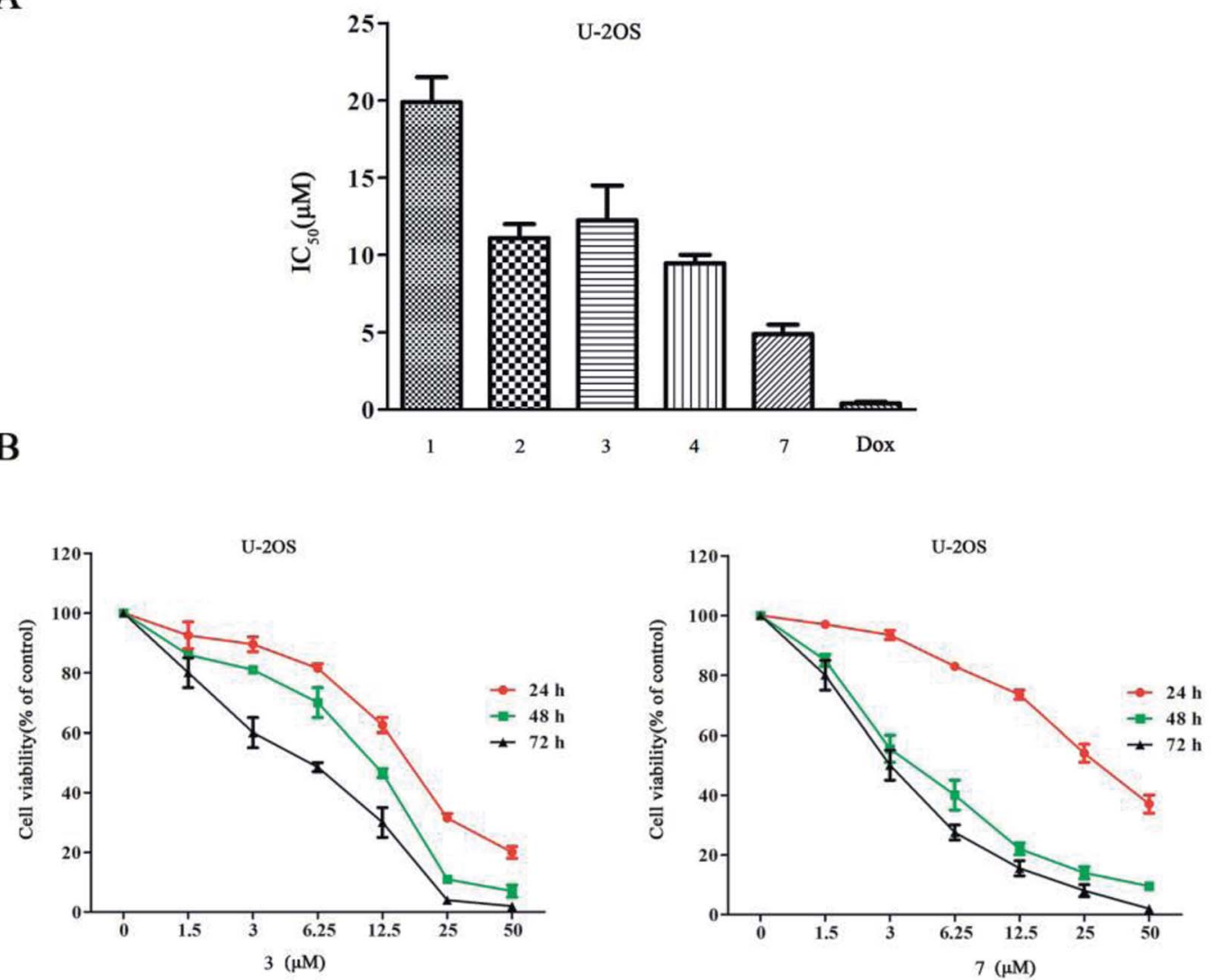

C

U-20S
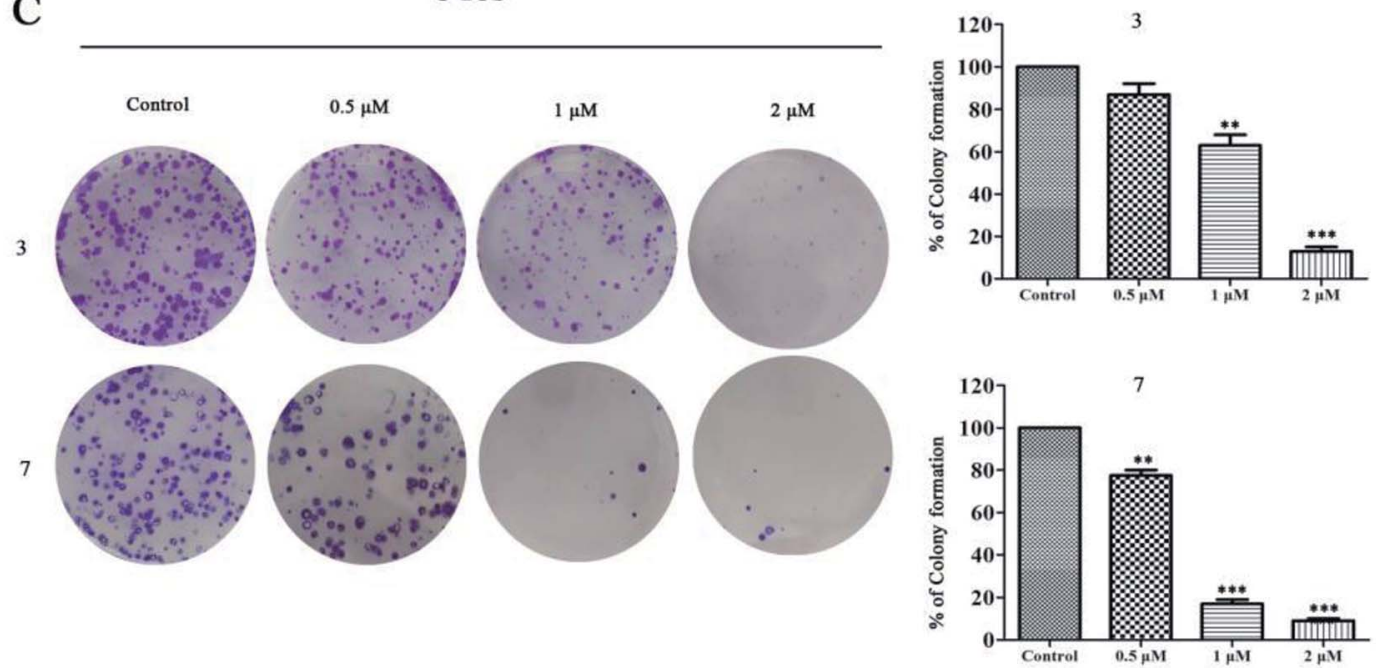

Fig. 8 The effects of stachybochartins $A-D(1-4)$ and $G(7)$ on cell viability in $U-2 O S$ cells and on inhibiting U-2OS cell proliferation. (A) U-2OS cells were treated with 1-4, 7 and DOX (positive control) for $48 \mathrm{~h}$, and the $\mathrm{IC}_{50}$ values were quantified using MTT assays. (B) U-2OS cells were treated with different concentrations of 3 and $7(0,1.5,3,6.25,12.5,25$ or $50 \mu \mathrm{M})$ for the indicated times, and cell viability was determined via MTT assays. (C) The effects of 3 and 7 on the clonogenic ability of $U-2 O S$ cells treated for $48 \mathrm{~h}$ are shown. The data are presented as mean $\pm \mathrm{SEM}$ from three independent experiments. *: $P<0.05, * *$ : $P<0.01$ and ***: $P<0.001$, compared to the control.

apoptosis in the cells. The caspase-cascade system plays a crucial role in cell apoptosis, and caspases are the executors of apoptosis. ${ }^{26}$ Therefore, we examined the expression of caspase-related proteins in stachybochartin G-treated U-2OS cells. Significant caspase-8, caspase-9 and PARP processing were observed in the total cell lysates, and their cleavages markedly increased in a dose-dependent manner (Fig. 9B). Thus, these data suggest that the cytotoxic effects of 
A

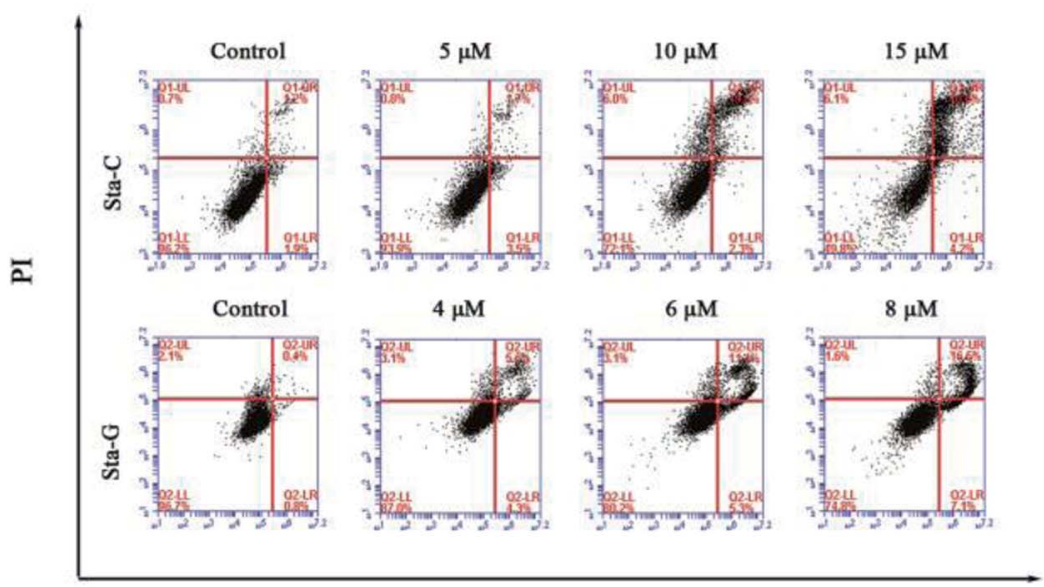

Annexin V-FITC

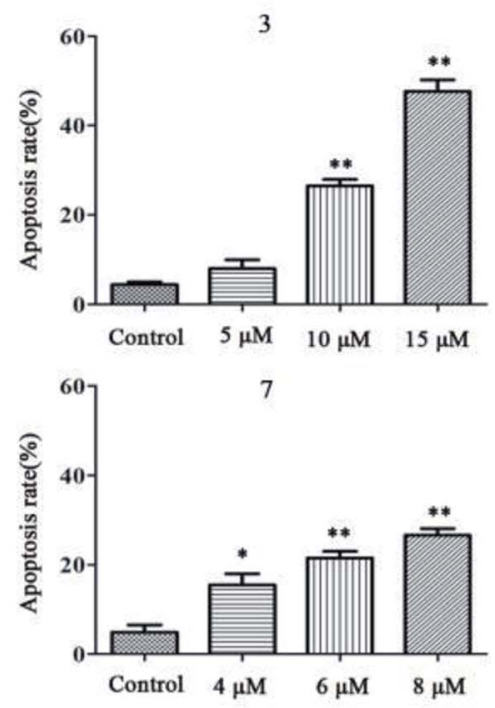

B
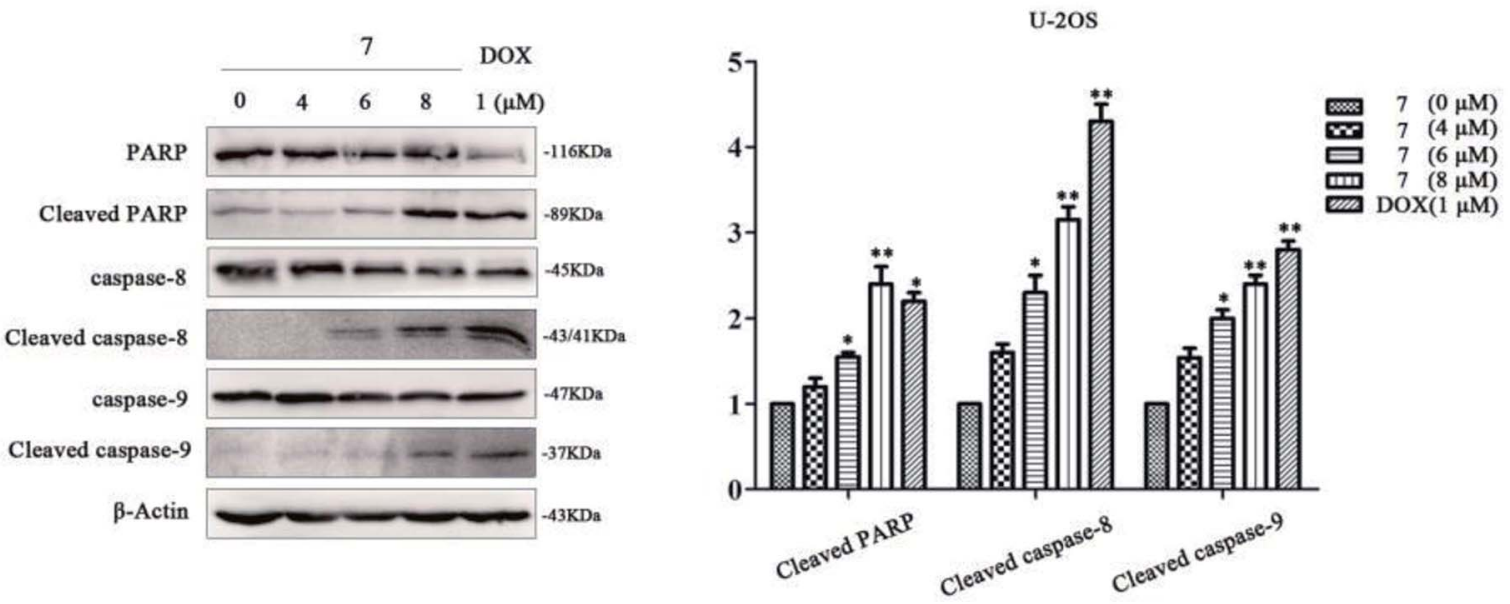

Fig. 9 Stachybochartins C (3) and G (7) induced caspase-dependent apoptosis in U-2OS cells. (A) U-2OS cells were pretreated with 3 (0-15 $\mu$ M) or $7(0-8 \mu \mathrm{M})$ for $48 \mathrm{~h}$ and apoptosis rates were analyzed via flow cytometry. (B) After treatment with $7(0-8 \mu \mathrm{M})$ and $\mathrm{DOX}(1 \mu \mathrm{M}$, as a positive control) for $48 \mathrm{~h}$, the expression levels of PARP and cleaved PARP, pro-caspase-8, cleaved caspase-8, pro-caspase-9, and cleaved caspase-9, were analyzed via western blotting. $\beta$-Actin was used as a protein loading control. The data are presented as mean \pm SEM from three independent experiments. *: $P<0.05$ and $* *: P<0.01$, compared to the control.

stachybochartin $\mathrm{G}$ on $\mathrm{U}-2 \mathrm{OS}$ cells were caused by the activation of caspase-dependent apoptosis.

\section{Conclusions}

In conclusion, seven phenylspirodrimane derivatives, stachybochartins A-G (1-7), together with four known analogues were isolated from the endophytic fungus Stachybotrys chartarum. The four dimers are structurally infrequent, especially stachybochartins A and B with their $\mathrm{C7}^{\prime}-\mathrm{C} 7^{\prime \prime \prime}$ linkages. The dimers, along with stachybochartin G, displayed cytotoxic activities against human MDA-MB-231 breast cancer cells and U-2OS osteosarcoma cancer cells, and the activation of caspase-dependent apoptosis was the possible pathway for their anticancer activities. In addition, stachybochartin $\mathrm{G}$, which features a seco-bisabosqual skeleton, showed stronger activity than normal phenylspirodrimanes. These findings may provide evidence for further research into the anticancer activities of these compounds.

\section{Experimental section}

\subsection{General experimental procedures}

Optical rotations were measured with a Jasco P-1020 polarimeter (Jasco, Tokyo, Japan). UV spectra were acquired with 
a Shimadzu UV-2450 spectrophotometer (Shimadzu, Tokyo, Japan). CD spectra were recorded using a Jasco J-810 spectrometer (Jasco, Tokyo, Japan). IR spectra ( $\mathrm{KBr}$ disks, in $\mathrm{cm}^{-1}$ ) were obtained using a Bruker Tensor 27 spectrometer (Bruker, Karlsruhe, Germany). NMR spectra $\left({ }^{1} \mathrm{H}: 500 \mathrm{MHz} ;{ }^{13} \mathrm{C}: 125\right.$ $\mathrm{MHz}$ ) were recorded at $300 \mathrm{~K}$ with a Bruker Avance III NMR instrument (Bruker, Karlsruhe, Germany), with TMS as the internal standard. $\mathrm{CD}_{3} \mathrm{OD}\left(\delta_{\mathrm{H}}=3.31\right.$ and $\left.\delta_{\mathrm{C}}=49.15\right)$ was used as the solvent. High-resolution electrospray ionization mass spectra (HRESIMS) data were obtained using an Agilent 6520B UPLC-Q-TOF instrument (Agilent Technologies, Santa Clara, CA, USA). Column chromatography (CC) was carried out using silica gel (Qingdao Marine Chemical Co. Ltd., Qingdao, China), Sephadex LH-20 (Pharmacia, Stockholm, Sweden), and RP-C18 silica (40-63 $\mu \mathrm{m}$, Fuji, Japan). The fractions obtained from column chromatography were studied via TLC with precoated silica gel GF254 (Qingdao Haiyang Chemical Co., Ltd., China) plates. Analytical HPLC was performed using an Agilent 1200 Series instrument with a DAD detector, using a Shimpack VPODS column $(5 \mu \mathrm{m}, 4.6 \times 250 \mathrm{~mm}$; Agilent Technologies, Palo Alto, CA, USA). Preparative HPLC was carried out using Shimadzu LC-10A apparatus equipped with a Shim-pack RP-C18 column $(10 \mu \mathrm{m}, 20 \times 200 \mathrm{~mm}$, i.d., Shimadzu, Tokyo, Japan) and Shimadzu SPD-20A detector.

\subsection{Fungal materials and fermentation}

The fungal strain Stachybotrys chartarum PT2-12 was isolated from rhizomes of Pinellia ternata, which were collected from the suburb of Nanjing, Jiangsu Province, People's Republic of China, in October 2014. It was identified according to morphological studies, which were reinforced by $18 \mathrm{~S}$ rDNA and internal transcribed spacer (ITS) sequences with $100 \%$ identity matching to known S. chartarum (GenBank accession No. KC787692.1).

The fungus $S$. chartarum was cultured on potato dextrose agar (PDA) at $28{ }^{\circ} \mathrm{C}$. Seven days later, agar plugs were cut into small pieces (about $0.3 \times 0.3 \times 0.3 \mathrm{~cm}^{3}$ ) under aseptic conditions, 3-4 pieces of which were inoculated in an Erlenmeyer flask $(500 \mathrm{~mL})$ containing $200 \mathrm{~mL}$ of potato dextrose liquid medium. Then the flasks were incubated on a rotary shaker at $28{ }^{\circ} \mathrm{C}$ and $160 \mathrm{rpm}$ for 7 days to prepare the seed culture. Fermentation was carried out in 30 Erlenmeyer flasks (2 L), each containing $320 \mathrm{~g}$ of rice and $400 \mathrm{~mL}$ of distilled $\mathrm{H}_{2} \mathrm{O}$; these were cultivated at $28{ }^{\circ} \mathrm{C}$ for 45 days. The solid culture medium was soaked overnight and sterilized at $121{ }^{\circ} \mathrm{C}$ for $20 \mathrm{~min}$ before use.

\subsection{Extraction and isolation}

The solid rice material was extracted with an equal volume of ethyl acetate (EtOAc) three times at room temperature, and the

Table $1{ }^{1} \mathrm{H}(500 \mathrm{MHz})$ and ${ }^{13} \mathrm{C}(125 \mathrm{MHz})$ NMR data for 1 and 2 in $\mathrm{CD}_{3} \mathrm{OD}$

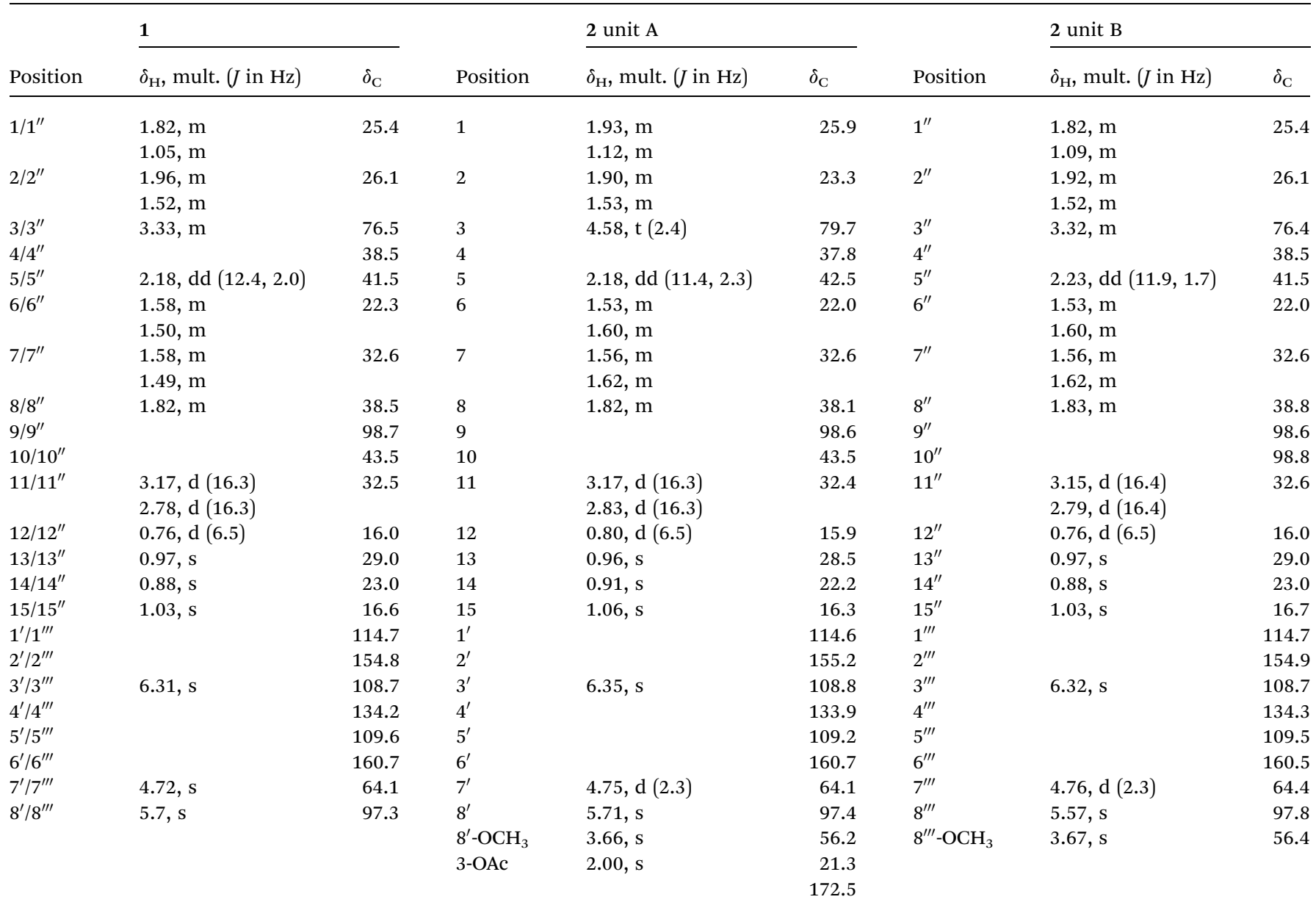


organic solvent was evaporated to dryness under vacuum to afford the crude extract (213.0 g). The EtOAc extract was fractionated via silica gel CC using PE (petroleum ether)-EtOAc (v/v: $80: 1,40: 1,20: 1,10: 1,5: 1,2: 1,1: 1$ and $0: 1)$ gradient elution to give eight fractions (Fr.1-Fr.8). Fr.7 (1:1, $789 \mathrm{mg}$ ) was subjected to Sephadex LH-20 CC with $\mathrm{CH}_{2} \mathrm{Cl}_{2}-\mathrm{MeOH}(1: 1)$ as the eluent, giving nine subfractions (Fr.7.1-Fr.7.9) after combination according to TLC. Fr.7.7 (64.7 mg) was separated via RP-HPLC, eluted with $\mathrm{CH}_{3} \mathrm{CN}-\mathrm{H}_{2} \mathrm{O}(42: 58)$ at a flow rate of $10.0 \mathrm{~mL} \mathrm{~min}{ }^{-1}$, to afford $5\left(1.7 \mathrm{mg} ; t_{\mathrm{R}}=23.6 \mathrm{~min}\right), 8\left(3.2 \mathrm{mg} ; t_{\mathrm{R}}\right.$ $=33.5 \mathrm{~min})$, and 9 (45.4 mg; $\left.t_{\mathrm{R}}=44.8 \mathrm{~min}\right)$. Fr.8 $(0: 1 ; 21.4 \mathrm{~g})$ was repeatedly subjected to chromatography using an ODS column, eluting with gradient $\mathrm{MeOH}-\mathrm{H}_{2} \mathrm{O}(\mathrm{v} / \mathrm{v}: 20: 80,30: 70$, $40: 60,50: 50,60: 40,80: 20$ and $100: 0)$, giving seven subfractions (Fr.8.1-Fr.8.7) after combination according to TLC. The subfraction Fr.8.4 was purified via preparative HPLC with $\mathrm{CH}_{3} \mathrm{CN}-\mathrm{H}_{2} \mathrm{O}$ (40:60), to give $7\left(5.8 \mathrm{mg} ; t_{\mathrm{R}}=32.3 \mathrm{~min}\right)$. Fr.8.5 was purified via preparative HPLC with $\mathrm{CH}_{3} \mathrm{CN}-\mathrm{H}_{2} \mathrm{O}(50: 50)$, to give 6 ( $\left.4.8 \mathrm{mg} ; t_{\mathrm{R}}=18.8 \mathrm{~min}\right), 10\left(17.6 \mathrm{mg}, t_{\mathrm{R}}=26.5 \mathrm{~min}\right)$, and $11\left(31.0 \mathrm{mg} ; t_{\mathrm{R}}=39.9 \mathrm{~min}\right)$. Fr.8.6 (1.0 g) was further separated via medium pressure preparative HPLC (ODS MPLC) with $\mathrm{MeOH}-\mathrm{H}_{2} \mathrm{O}$ (85 : 15), to give eight fractions (Fr.8.6.1-Fr.8.6.8). Fr.8.6.3 (143.1 $\mathrm{mg}$ ) was purified via preparative HPLC with $\mathrm{CH}_{3} \mathrm{CN}-\mathrm{H}_{2} \mathrm{O}(70: 30)$ to give $3\left(39.1 \mathrm{mg} ; t_{\mathrm{R}}=13.1 \mathrm{~min}\right)$ and 2 (9.6 $\left.\mathrm{mg} ; t_{\mathrm{R}}=34.1 \mathrm{~min}\right)$. Fr.8.6.4 (116.3 mg) was purified via preparative HPLC with $\mathrm{CH}_{3} \mathrm{CN}-\mathrm{H}_{2} \mathrm{O}$ (70:30) to give 1 (15.9 mg; $t_{\mathrm{R}}$ $=22.8 \mathrm{~min}$ ). Fr.8.6.7 (89.9 $\mathrm{mg}$ ) was purified via preparative HPLC with $\mathrm{CH}_{3} \mathrm{CN}-\mathrm{H}_{2} \mathrm{O}(85: 15)$ to give $4\left(17.2 \mathrm{mg}, t_{\mathrm{R}}=12.9 \mathrm{~min}\right)$.

Stachybochartin A (1). Yellow powder; $[\alpha]_{\mathrm{D}}^{25}:-33.5(c \quad 0.12$, $\mathrm{MeOH}) ; \mathrm{UV}(\mathrm{MeOH}) \lambda_{\max }(\log \varepsilon): 213$ (4.27), 288 (3.25) nm; IR (KBr) $v_{\text {max }}: 3429,2928,1629,1458,1358,1261,1123,1083,1038$, $960 \mathrm{~cm}^{-1}$; CD (MeOH) $\lambda_{\max }(\Delta \varepsilon): 202(+31.9), 214(-48.1)$, and $242(+3.2) \mathrm{nm} ;{ }^{1} \mathrm{H}$ and ${ }^{13} \mathrm{C}$ NMR data: see Table 1 ; HRESIMS $m / z$ : 797.4232 $[\mathrm{M}+\mathrm{Na}]^{+}$(calcd for $\mathrm{C}_{46} \mathrm{H}_{62} \mathrm{NaO}_{10}$ : 797.4235).

Stachybochartin B (2). Yellow powder; $[\alpha]_{\mathrm{D}}^{25}$ : $-63.6(c 0.14$, $\mathrm{MeOH}) ; \mathrm{UV}(\mathrm{MeOH}) \lambda_{\max }(\log \varepsilon): 213$ (4.82), 288 (3.66) nm; IR (KBr) $v_{\text {max }}: 3431,2925,1713,1630,1457,1382,1263,1124,1083$, 1038, $962 \mathrm{~cm}^{-1}$; CD $(\mathrm{MeOH}) \lambda_{\max }(\Delta \varepsilon): 202(+21.3), 214(-33.6)$, and $241(+2.8) \mathrm{nm} ;{ }^{1} \mathrm{H}$ and ${ }^{13} \mathrm{C}$ NMR data: see Table 1 ; HRESIMS $m / z: 867.4658[\mathrm{M}+\mathrm{Na}]^{+}$(calcd for $\mathrm{C}_{50} \mathrm{H}_{68} \mathrm{NaO}_{11}$ : 867.4654).

Table $2{ }^{1} \mathrm{H}(500 \mathrm{MHz})$ and ${ }^{13} \mathrm{C}(125 \mathrm{MHz})$ NMR data for 3 and 4 in $\mathrm{CD}_{3} \mathrm{OD}$

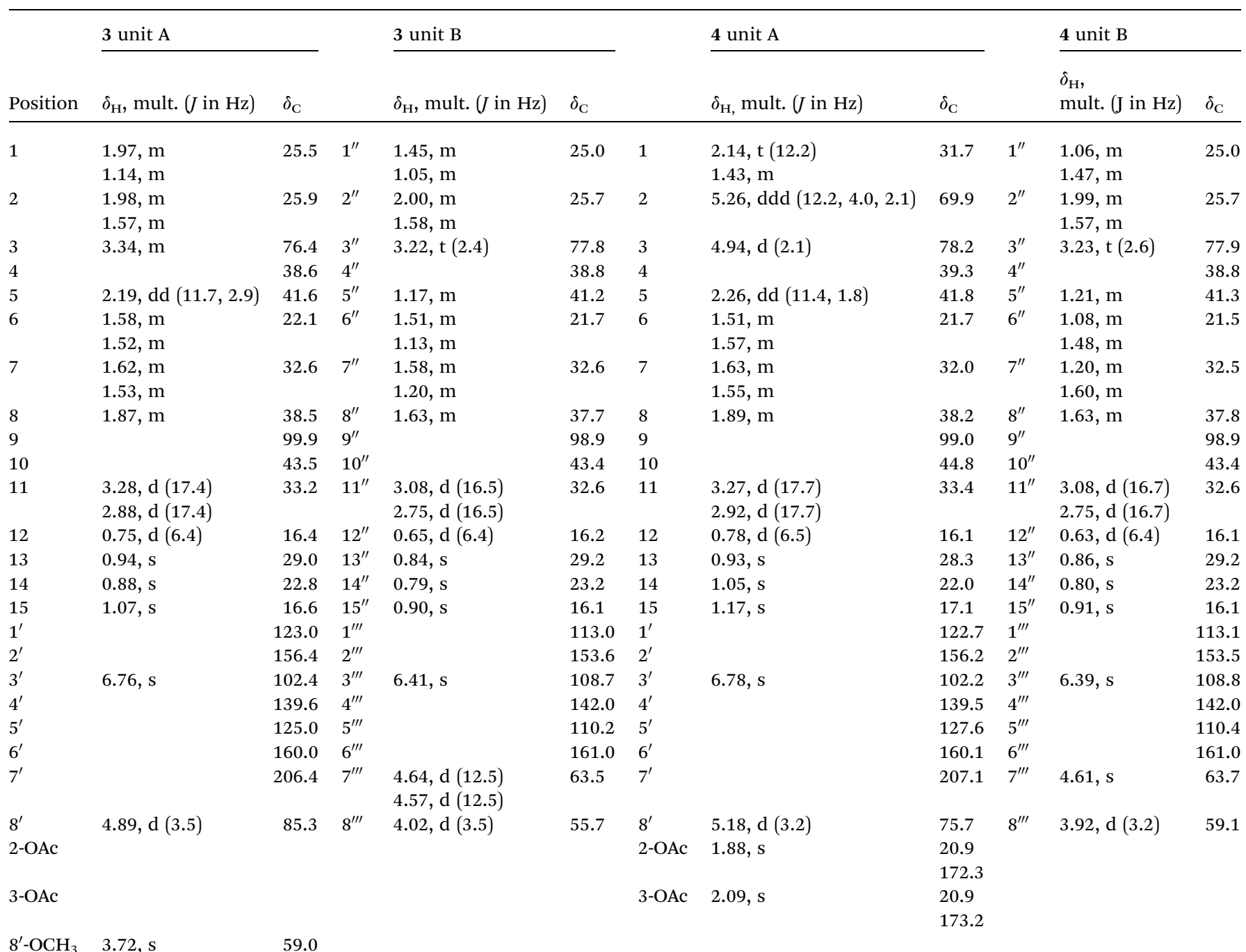


Stachybochartin C (3). White powder; $[\alpha]_{\mathrm{D}}^{25}:-38.3(c \quad 0.13$, $\mathrm{MeOH}) ; \mathrm{UV}(\mathrm{MeOH}) \lambda_{\max }(\log \varepsilon): 214$ (4.63), 287 (3.89) nm; IR (KBr) $v_{\text {max }}: 3429,2932$, 2877, 1705, 1623, 1459, 1386, 1350, 1255, $1112 \mathrm{~cm}^{-1}$; CD $(\mathrm{MeOH}) \lambda_{\max }(\Delta \varepsilon): 202(+1.0), 219(+16.5), 237$ $(-10.1), 251(-0.3), 288(-9.0)$, and $345(+3.3) \mathrm{nm} ;{ }^{1} \mathrm{H}$ and ${ }^{13} \mathrm{C}$ NMR data: see Table 2; HRESIMS $m / z$ : $795.4447[\mathrm{M}+\mathrm{Na}]^{+}$(calcd for $\mathrm{C}_{47} \mathrm{H}_{64} \mathrm{NaO}_{9}$ : 795.4443).

Stachybochartin D (4). White powder; $[\alpha]_{\mathrm{D}}^{25}:-29.2$ (c 0.12, $\mathrm{MeOH}$ ); UV (MeOH) $\lambda_{\max }(\log \varepsilon): 213$ (4.15), 287 (3.43) nm; IR (KBr) $v_{\text {max }}: 3431,2921,2851,1713,1629,1464,1385,1260,1125$, $621 \mathrm{~cm}^{-1}$; CD $(\mathrm{MeOH}) \lambda_{\max }(\Delta \varepsilon): 205(+1.0), 220(+21.9), 236$ $(-19.0), 250(-1.2), 288(-15.4)$, and $344(+5.4) \mathrm{nm} ;{ }^{1} \mathrm{H}$ and ${ }^{13} \mathrm{C}$ NMR data: see Table 2; HRESIMS $m / z: 857.4478[\mathrm{M}-\mathrm{H}]^{-}$(calcd for $\mathrm{C}_{50} \mathrm{H}_{65} \mathrm{O}_{12}$ : 857.4482).

Stachybochartin E (5). Pale yellow powder; $[\alpha]_{\mathrm{D}}^{25}$ : $-8.2(c 0.10$, $\mathrm{MeOH}) ; \mathrm{UV}(\mathrm{MeOH}) \lambda_{\max }(\log \varepsilon): 219$ (4.09), 268 (3.34), 309
(3.08) nm; IR (KBr) $\nu_{\max }: 3419,2922,2851,1744,1628,1469$, 1384, 1334, 1261, 1126, 1088, 957, $619 \mathrm{~cm}^{-1}$; CD (MeOH) $\lambda_{\max }$ $(\Delta \varepsilon): 219(+3.77), 268(-1.04)$, and $339(-0.28) \mathrm{nm} ;{ }^{1} \mathrm{H}$ and ${ }^{13} \mathrm{C}$ NMR data: see Table 3; HRESIMS $m / z: 467.2038[\mathrm{M}+\mathrm{Na}]^{+}$(calcd for $\mathrm{C}_{25} \mathrm{H}_{32} \mathrm{NaO}_{7}$ : 467.2040).

Stachybochartin F (6). Yellow powder; $[\alpha]_{\mathrm{D}}^{25}$ : $-27.7(c \quad 0.14$, $\mathrm{MeOH}) ; \mathrm{UV}(\mathrm{MeOH}) \lambda_{\max }(\log \varepsilon): 218$ (4.16), 264 (3.52), 300 (3.14) nm; IR (KBr) $\nu_{\text {max }}: 3422,2924,2875,1742,1670,1468$, 1387, 1349, 1239, 1142, 1079, $622 \mathrm{~cm}^{-1}$; CD $(\mathrm{MeOH}) \lambda_{\max }(\Delta \varepsilon)$ : $215(+2.29), 264(-2.41)$, and $338(-0.17) \mathrm{nm} ;{ }^{1} \mathrm{H}$ and ${ }^{13} \mathrm{C}$ NMR data: see Table 3; HRESIMS $m / z: 472.2693[\mathrm{M}+\mathrm{H}]^{+}$(calcd for $\mathrm{C}_{27} \mathrm{H}_{38} \mathrm{NO}_{6}$ : 472.2694).

Stachybochartin G (7). Yellow gum; $[\alpha]_{\mathrm{D}}^{25}:-27.8(c \quad 0.10$, $\mathrm{MeOH}) ; \mathrm{UV}(\mathrm{MeOH}) \lambda_{\max }(\log \varepsilon): 220$ (4.00), 258 (3.41), 262 (3.42), 282 (3.00) nm; IR (KBr) $\nu_{\max }$ : 3423, 2921, 2851, 1648, 1384, 1126, $619 \mathrm{~cm}^{-1}$; CD $(\mathrm{MeOH}) \lambda_{\max }(\Delta \varepsilon): 219(+18.1), 259$

Table $3{ }^{1} \mathrm{H}(500 \mathrm{MHz})$ and ${ }^{13} \mathrm{C}(125 \mathrm{MHz}) \mathrm{NMR}$ data for compounds 5-7 in $\mathrm{CD}_{3} \mathrm{OD}$

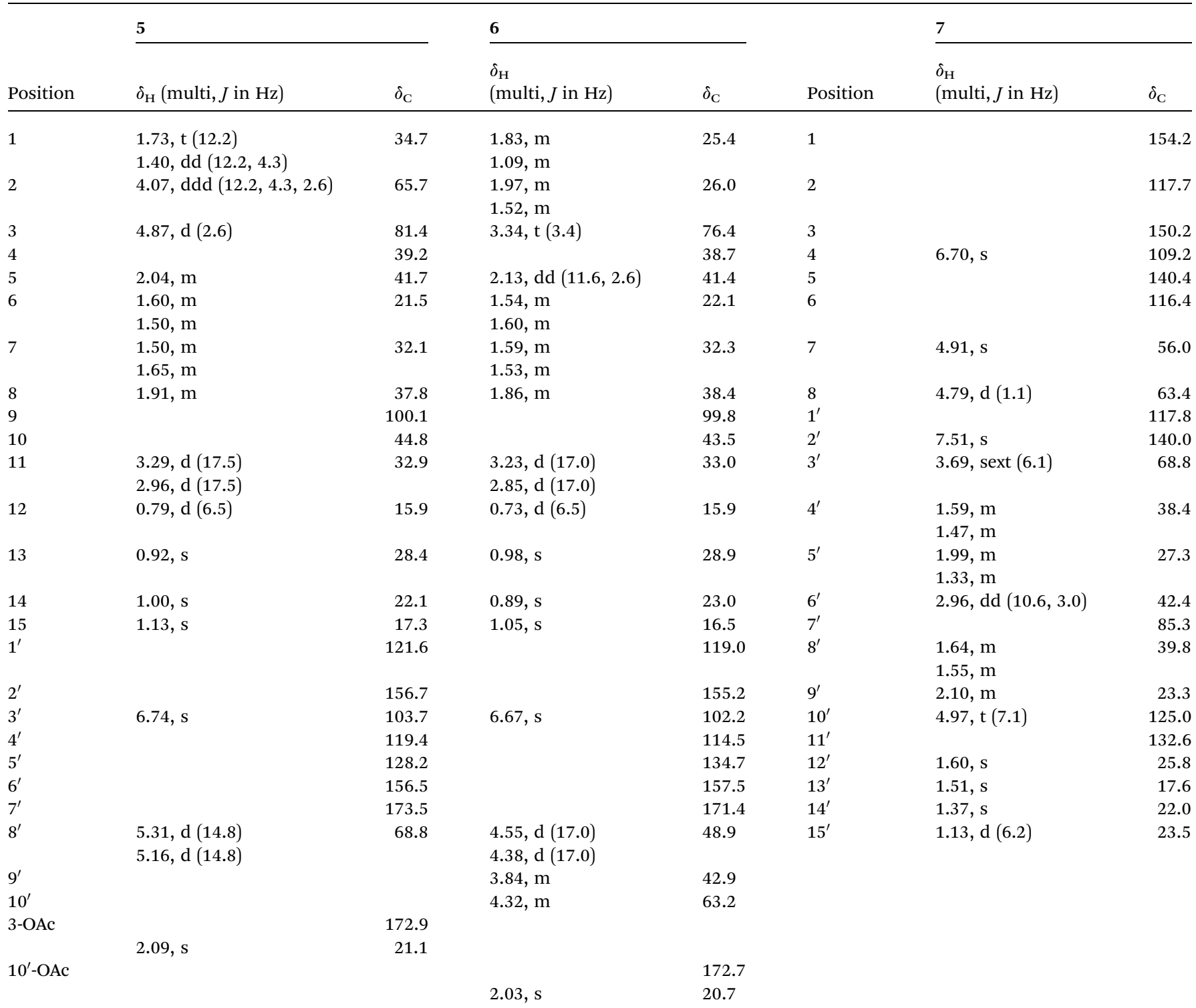


(-7.1) nm; ${ }^{1} \mathrm{H}$ and ${ }^{13} \mathrm{C}$ NMR data: see Table 3; HRESIMS $m / z$ : 411.2141 [M $+\mathrm{Na}]^{+}$(calcd for $\mathrm{C}_{23} \mathrm{H}_{32} \mathrm{NaO}_{5}$ : 411.2142).

\subsection{Cell cultures}

MDA-MB-231 (human triple-negative breast cancer), MCF-7 (human breast cancer) and U-2OS (human osteosarcoma) cells were obtained from the Cell Bank of the Shanghai Institute of Biochemistry and Cell Biology, Chinese Academy of Sciences (Shanghai, China). MDA-MB-231 was cultured in DMEM medium. MCF-7 cells and U-2OS cells were cultured in RPMI1640 medium. All cell lines were supplemented with 10\% FBS containing $50 \mu \mathrm{g} \mathrm{mL}^{-1}$ penicillin and $50 \mu \mathrm{g} \mathrm{mL}^{-1}$ streptomycin, and were grown in an incubator at $37^{\circ} \mathrm{C}$ with $5.0 \% \mathrm{CO}_{2}$ under a humidified environment.

\subsection{Cell viability assays and colony formation assays}

Cell viability was measured via a standard colorimetric test using MTT. Cells were plated in standard 96-well culture plates $\left(5 \times 10^{3}\right.$ cells per well). After a $24 \mathrm{~h}$ period of incubation, cells were treated with various concentrations of stachybochartin $\mathrm{C}$ (3) or stachybochartin G (7) for 24, 48 and $72 \mathrm{~h}$. DMSO (0.1\%) was used as a vehicle, the final concentration of which was less than $0.1 \%(\mathrm{v} / \mathrm{v}) .20 \mu \mathrm{L}$ of MTT $\left(5 \mathrm{mg} \mathrm{mL}^{-1}\right)$ solution was added to each well and the plates were incubated for about four hours. The formed formazan crystals were dissolved in DMSO $(150 \mu \mathrm{L}$ per well) under constant shaking for $10 \mathrm{~min}$. The absorbance of formazan production was measured using an ELISA reader (SpectraMax Plus384, Molecular Devices, Sunnyvale, CA) at $570 \mathrm{~nm}$ (test wavelength) and $650 \mathrm{~nm}$ (reference wavelength). Cell viability was calculated via the following formula:

$$
\% \text { cell viability }=\left(A_{\mathrm{t}} / A_{\mathrm{s}}\right) \times 100 \%
$$

where $A_{\mathrm{t}}$ and $A_{\mathrm{s}}$ denote the absorbances of the test substance and solvent control, respectively.

For colony formation, 1000 cells were plated in 6-well culture plates. After treatment with various concentrations of stachybochartin $\mathrm{C}$, stachybochartin G, and 0.1\% DMSO for 14 days, the cells were stained with crystal violet solution (Beyotime, Jiangsu, China). The cell viability assays and colony formation assays were performed as previously described. ${ }^{27}$

\subsection{Annexin V-Alexa Fluor 647/PI staining assay for cell apoptosis}

U-2OS cells were treated with various concentrations of stachybochartin C or stachybochartin G for $48 \mathrm{~h}$. For flow cytometry, $1 \times$ $10^{6}$ cells in $100 \mu \mathrm{L}$ of binding buffer were stained with $5 \mu \mathrm{L}$ of Annexin V-Alexa Fluor 647 (BD Biosciences, San Jose, CA, USA) and $5 \mu \mathrm{L}$ of PI (Miltenyi Biotec, Shanghai, China). After incubation at room temperature and protection from light for $30 \mathrm{~min}$, the cells were then analyzed via flow cytometry (488 $\mathrm{nm}$ excitation and $647 \mathrm{~nm}$ emission filters) using a BD Accuri C6 flow cytometer.

\subsection{Western blot analysis}

$\mathrm{U}-2 \mathrm{OS}$ cells were incubated with various concentrations of stachybochartin $\mathrm{G}$ or $0.1 \%$ DMSO for $24 \mathrm{~h}$. After harvesting, the cells were treated with cell lysis buffer (Beyotime, Jiangsu, China) to extract the total proteins and centrifuged at $12000 \mathrm{rpm}$ for $10 \mathrm{~min}$. Proteins were extracted for western blot analysis, as previously described. ${ }^{28}$ Bound immuno-complexes were detected using the ChemiDOC ${ }^{\mathrm{TM}}$ XRS+ system (BioRad Laboratories, Hercules, CA).

\section{Conflicts of interest}

The authors declare that they have no conflicts of interest.

\section{Acknowledgements}

This research work was supported by the National Natural Science Foundation of China (81602985), the Program for Changjiang Scholars and the Innovative Research Team in University (IRT_15R63), the 111 Program of Introducing Talents of Discipline to Universities (B18056), and the Priority Academic Program Development of Jiangsu Higher Education Institutions (PAPD). The ECD calculations were supported by the High Performance Computing Center, China Pharmaceutical University.

\section{References}

1 A. Wang, Y. Xu, Y. Gao, Q. Huang, X. Luo, H. An and J. Dong, Phytochem. Rev., 2014, 14, 623-655.

2 J. W. Kim, S. K. Ko, H. M. Kim, G. H. Kim, S. Son, G. S. Kim, G. J. Hwang, E. S. Jeon, K. S. Shin, I. J. Ryoo, Y. S. Hong, H. Oh, K. H. Lee, N. K. Soung, D. Hashizume, T. Nogawa, S. Takahashi, B. Y. Kim, H. Osada, J. H. Jang and J. S. Ahn, J. Nat. Prod., 2016, 79, 2703-2708.

3 S. Sawadjoon, P. Kittakoop, M. Isaka, K. Kirtikara, S. Madla and Y. Thebtaranonth, Planta Med., 2004, 70, 1085-1087.

4 H. Kaise, M. Shinohara, W. Miyazaki, T. Izawa, Y. Nakano, M. Sugawara, K. Sugiura and K. Sasaki, J. Chem. Soc., Chem. Commun., 1979, 16, 726-727.

5 M. J. Vázquez, A. Vega, A. Rivera-Sagredo, M. D. JiménezAlfaro, E. Díez and J. A. Hueso-Rodríguez, Tetrahedron, 2004, 60, 2379-2385.

6 Y. Li, C. Wu, D. Liu, P. Proksch, P. Guo and W. Lin, J. Nat. Prod., 2014, 77, 138-147.

7 E. J. Corey and J. Das, J. Am. Chem. Soc., 1982, 104, 55515553.

8 M. J. Cano, H. Bouanou, R. Tapia, E. Alvarez, R. AlvarezManzaneda, R. Chahboun and E. Alvarez-Manzaneda, J. Org. Chem., 2013, 78, 9196-9204.

9 J. R. Falck, K. Kishta Reddy and S. Chandrasekhar, Tetrahedron Lett., 1997, 38, 5245-5248.

10 K. Ogawa, M. Nakamura, M. Hayashi, S. Yaginuma, S. Yamamoto, K. Furihataf, K. Shin-yaft and H. Seto, J. Antibiot., 1995, 48, 1396-1400.

11 B. Wu, V. Oesker, J. Wiese, S. Malien, R. Schmaljohann and J. F. Imhoff, Mar. Drugs, 2014, 12, 1924-1938.

12 Y. Li, C. Wu, D. Liu, P. Proksch, P. Guo and W. Lin, J. Nat. Prod., 2014, 77, 435. 
13 Z. G. Ding, J. H. Ding, J. Y. Zhao, W. X. Chunyu, M. G. Li, S. J. Gu, F. Wang and M. L. Wen, Fitoterapia, 2018, 125, 94-97.

14 Z. G. Ding, J. Y. Zhao, J. H. Ding, W. X. Chunyu, M. G. Li, S. J. Gu, F. Wang and M. L. Wen, Nat. Prod. Res., 2018, 32, 2370-2374.

15 B. E. Roggo, P. Hug, S. Moss, A. Stampfli, H. P. Kriemler and H. H. Peter, J. Antibiot., 1996, 49, 374-379.

16 T. X. Li, M. H. Yang, Y. Wang, X. B. Wang, J. Luo, J. G. Luo and L. Y. Kong, Sci. Rep., 2016, 6, 38958.

17 S. Gombodorj, M. H. Yang, Z. C. Shang, R. H. Liu, T. X. Li, G. P. Yin and L. Y. Kong, Fitoterapia, 2017, 120, 72-78.

18 M. H. Yang, T. X. Li, Y. Wang, R. H. Liu, J. Luo and L. Y. Kong, Fitoterapia, 2017, 116, 72-76.

19 N. Gao, Z. C. Shang, P. Yu, J. Luo, K. L. Jian, L. Y. Kong and M. H. Yang, Chin. Chem. Lett., 2017, 28, 1194-1199.

20 Y. J. Kwon, M. J. Sohn, H. J. Kim and W. G. Kim, Biol. Pharm. Bull., 2014, 37, 1406-1410.
21 N. Berova, L. D. Bari and G. Pescitelli, Chem. Soc. Rev., 2007, 36, 914-931.

22 W. S. Li, J. Wu, J. Li, T. Satyanandamurty, L. Shen and G. Bringmann, Org. Lett., 2017, 19, 182-185.

23 B. B. Jarvis, J. Salemme and A. Morais, Nat. Toxins, 1995, 3, 10-16.

24 J. Zhao, J. Feng, Z. Tan, J. Liu, J. Zhao, R. Chen, K. Xie, D. Zhang, Y. Li, L. Yu, X. Chen and J. Dai, J. Nat. Prod., 2017, 80, 1819-1826.

25 Y. R. Bao, G. D. Chen, Y. H. Wu, X. X. Li, D. Hu, X. Z. Liu, Y. Li, X. S. Yao and H. Gao, Fitoterapia, 2015, 105, 151-155.

26 K. M. Boatright and G. S. Salvesen, Curr. Opin. Cell Biol., 2003, 15, 725-731.

27 C. Zhang, L. Yang, X. B. Wang, J. S. Wang, Y. D. Geng, C. S. Yang and L. Y. Kong, Cancer Lett., 2013, 340, 51-62.

28 J. Zhang, J. Chiu, H. Zhang, T. Qi, Q. Tang, K. Ma, H. Lu and G. Li, Biochem. Pharmacol., 2013, 86, 317-328. 